American Journal of Animal and Veterinary Sciences 3 (2): 62-67, 2008

ISSN 1557-4555

(C) 2008 Science Publications

\title{
Effect of Organic and Inorganic Chromium Supplementation on Meat Quality of Heat-Stressed Broiler Chicks
}

\author{
${ }^{1}$ Majid Toghyani, ${ }^{2}$ Ali Khodami and ${ }^{3}$ Abbas Ali Gheisari \\ ${ }^{1}$ Department of Animal Science, \\ Islamic Azad University, Khorasgan (Isfahan) Branch, Isfahan, Iran \\ ${ }^{2}$ Department of Food Science, \\ Islamic Azad University, Khorasgan (Isfahan) Branch, Isfahan, Iran \\ ${ }^{3}$ Department of Animal Science, Isfahan Agricultural Research Center, Isfahan, Iran
}

\begin{abstract}
This study examined the effect of different levels of dietary organic and inorganic chromium $(\mathrm{Cr})$ on meat quality of broiler chicks reared under heat stress condition. Four hundred and twenty Ross male chickens in heat stress condition $\left(33 \pm 3^{\circ} \mathrm{C}\right)$ were allocated to seven treatments in a completely randomized design. Treatments were supplemented with 0 (control), 500, 1000 or $1500 \mu \mathrm{g}$ $\mathrm{kg}^{-1} \mathrm{Cr}$ in the form of $\mathrm{Cr}$ nicotinate and $\mathrm{Cr}$ chloride. Twelve chicks from each treatment were slaughtered at $42 \mathrm{~d}$, to evaluate moisture, protein, lipid, $\mathrm{pH}$ and lipid oxidation of thigh and breast meat. Moisture, lipid and $\mathrm{pH}$ of meat were not affected by supplemental Cr. Breast meat protein was significantly $(\mathrm{p}<0.05)$ increased by the $\mathrm{Cr}$ supplementation especially organic $\mathrm{Cr}$. Storage time increased lipid oxidation of meat $(\mathrm{p}<0.01)$. Lipid oxidation of breast and thigh muscle for two days of storage were affected by supplemental $\mathrm{Cr}$ and decreased $(\mathrm{p}<0.05)$. Results of the present study showed that supplementation of diet with $\mathrm{Cr}$ can improve the meat quality of broiler chicks in heat stress condition.
\end{abstract}

Key words: Chicken, Heat stress, Organic and inorganic chromium, Meat quality

\section{INTRODUCTION}

Heat stress has long been recognized as having a detrimental effect on broiler production efficiency and meat yield $d^{[1,2]}$. Exposure to high ambient temperatures has been reported to cause undesirable changes in meat characteristics in broilers ${ }^{[3-5]}$. Trivalent $\mathrm{Cr}$ is an essential element in the animal body ${ }^{[6]}$ and is involved in carbohydrate, lipid, protein and nucleic acid metabolic functions ${ }^{[7]}$. Cr is also a cofactor of insulin, promoting insulin activity ${ }^{[8]}$ and enhancing amino acid uptake into muscular cells for protein synthesis ${ }^{[9]}$. Stress increased urinary excretion of $\mathrm{Cr}$ and may exacerbate a marginal $\mathrm{Cr}$ deficiency ${ }^{[10,11]}$. Dietary $\mathrm{Cr}$ supplementation has been reported to have a positive effect on meat quality ${ }^{[12,13]}$ and carcass traits of broiler chicks in natura ${ }^{[14,15]}$ or heat stress condition ${ }^{[16]}$. Certain organic $\mathrm{Cr}$ sources are suggested to be utilized more efficiently than inorganic $\mathrm{Cr}$ sources ${ }^{[7]}$. However, studies designed to compare the effectiveness of organic and inorganic sources of $\mathrm{Cr}$ on meat quality of broiler chicks are few.
With the heightened awareness of meat quality in the poultry industry and possible supplementation of $\mathrm{Cr}$ in broiler diets, the effects of $\mathrm{Cr}$ on meat quality need to be more clearly defined. Thus, the purpose of this study was to investigate the effects of two sources of $\mathrm{Cr}, \mathrm{Cr}$ nicotinate and $\mathrm{Cr}$ Chloride, on the meat quality of broiler chicks in heat stress condition.

\section{MATERIALS AND METHODS}

Animals and diets: From July 11 to Aug 20th, four hundred and twenty one-day-old commercial Ross male chicks were reared under heat stress condition. During the experiment, house's temperature was measured four times a day $(0600,1200,1800$ and 2400) and the mean value of daily temperature in the house was kept $33 \pm 3^{\circ} \mathrm{C}$. Birds were randomly allotted by body weight to one of seven treatments (four replicate pens of fifteen chicks per pen) in a completely randomized design. Broiler chicks were housed in floor pens (length 120 $\mathrm{cm} \times$ width $120 \mathrm{~cm} \times$ height $80 \mathrm{~cm}$ ) equipped with feeders and waterers. Chicks were maintained on a $23 \mathrm{~h}$ light

Corresponding Author: Majid Toghyani, Department of Animal Science, Islamic Azad University, Khorasgan (Isfahan) Branch, Isfahan, Iran Tel: +98-913-314-1302 Fax: +98-311-5354038 
American J. Animal \& Vet. Sci., 3 (2): 62-67, 2008

Table 2: Effects of organic and inorganic $\mathrm{Cr}$ supplementation on moisture, protein, lipid and $\mathrm{pH}$ of thigh and breast meat

\begin{tabular}{|c|c|c|c|c|c|c|c|c|}
\hline & \multirow[b]{2}{*}{ Control } & \multicolumn{3}{|c|}{ Cr chloride $\left(\mu \mathrm{g} \mathrm{kg}^{-1}\right)$} & \multicolumn{3}{|c|}{ Cr nicotinate $\left(\mu \mathrm{g} \mathrm{kg}^{-1}\right)$} & \multirow[b]{2}{*}{ SE } \\
\hline & & 500 & 1000 & 1500 & 500 & 1000 & 1500 & \\
\hline \multicolumn{9}{|l|}{ Breast } \\
\hline Moisture (\%) & 73.3 & 73.1 & 73.3 & 74.1 & 73.2 & 73.9 & 73.2 & 0.457 \\
\hline Protein $(\%)$ & $20.72^{\mathrm{d}}$ & $22.1^{\mathrm{cd}}$ & $22.98^{\mathrm{ab}}$ & $21.35^{\mathrm{cd}}$ & $23.5^{\mathrm{a}}$ & $22.58^{\mathrm{ab}}$ & $23.08^{\mathrm{ab}}$ & 0.403 \\
\hline Lipid (\%) & 0.994 & 1.05 & 1.31 & 1.14 & 1.25 & 1.19 & 1.21 & 0.265 \\
\hline $\mathrm{pH}$ & 5.73 & 5.95 & 5.94 & 5.80 & 5.83 & 5.83 & 5.89 & 0.088 \\
\hline \multicolumn{9}{|l|}{ Thigh } \\
\hline Moisture (\%) & 73.2 & 73.4 & 73.1 & 74.1 & 73.6 & 73.2 & 74.4 & 0.699 \\
\hline Protein (\%) & 17.27 & 17.40 & 17.87 & 18.15 & 18.30 & 17.75 & 18.76 & 0.570 \\
\hline Lipid (\%) & 5.96 & 6.50 & 6.57 & 5.30 & 6.17 & 5.12 & 4.96 & 0.737 \\
\hline $\mathrm{pH}$ & 6.17 & 6.37 & 6.33 & 6.31 & 6.26 & 6.20 & 6.22 & 0.065 \\
\hline
\end{tabular}

Table 3: Effects of organic and inorganic $\mathrm{Cr}$ supplementation on the lipid oxidation of thigh and breast meat (mg malonaldehyde $\mathrm{kg}^{-1}$ meat) following different refrigerated storage

\begin{tabular}{|c|c|c|c|c|}
\hline \multirow[b]{2}{*}{ Treatments } & \multicolumn{2}{|l|}{ Thigh } & \multicolumn{2}{|l|}{ Breast } \\
\hline & Day 2 & Day 6 & Day 2 & Day 6 \\
\hline Control & $0.935^{\mathrm{a}}$ & 1.418 & $0.492^{\mathrm{a}}$ & 0.562 \\
\hline \multicolumn{5}{|l|}{ Cr chloride $\left(\mu \mathrm{gg}^{-1}\right)$} \\
\hline 500 & $0.856^{\mathrm{ab}}$ & 1.465 & $0.334^{\mathrm{b}}$ & 0.458 \\
\hline 1000 & $0.659^{\mathrm{bc}}$ & 1.625 & $0.392^{\mathrm{ab}}$ & 0.474 \\
\hline 1500 & $0.696^{\mathrm{abc}}$ & 1.133 & $0.326^{\mathrm{b}}$ & 0.481 \\
\hline \multicolumn{5}{|c|}{ Cr nicotinate $\left(\mu \mathrm{g} \mathrm{kg}^{-1}\right)$} \\
\hline 500 & $0.663^{\mathrm{bc}}$ & 1.333 & $0.356^{\mathrm{b}}$ & 0.462 \\
\hline 1000 & $0.638^{\mathrm{bc}}$ & 1.377 & $0.264^{\mathrm{b}}$ & 0.441 \\
\hline 1500 & $0.568^{\mathrm{c}}$ & 1.293 & $0.305^{\mathrm{b}}$ & 0.431 \\
\hline SE & 0.079 & 0.120 & 0.044 & 0.057 \\
\hline
\end{tabular}

Table 2. Dietary $\mathrm{Cr}$ source and level had no effect $(\mathrm{p}>0.05)$ on moisture and intramuscular fat content of breast and thigh meat. Breast meat protein was significantly $(\mathrm{p}<0.05)$ increased by the $\mathrm{Cr}$ supplementation (Table 2). When the two $\mathrm{Cr}$ sources compared, broilers that consumed $\mathrm{Cr}$ nicotinate had more breast protein content than the broilers that consumed $\mathrm{Cr}$ chloride. Protein content of thigh muscle was also higher but not significantly $(p>0.05)$ in $\mathrm{Cr}$ supplemented groups compared with birds receiving no Cr supplementation.

pH value: Breast and thigh muscle $\mathrm{pH}$ was not significantly influenced by the source and level of supplemental $\mathrm{Cr}$ (Table 2). However, muscle $\mathrm{pH}$ tended to increase with supplemental $\mathrm{Cr}$ especially in $\mathrm{Cr}$ chloride groups.

Lipid oxidation: The effects of supplemental organic and inorganic $\mathrm{Cr}$ on lipid oxidation of thigh and breast muscle are presented in Table 3. The results of oxidative stability of breast and thigh meat stored under refrigerated conditions show that oxidation of both, the breast and thigh meat, occurred slowly and followed a linear increase in oxidation with length of storage. TBARs value of thigh muscle in each storage time was higher than breast muscle $(\mathrm{p}<0.05)$. The breast and thigh meat of birds fed the organic and inorganic $\mathrm{Cr}$ showed a reduction $(p<0.05)$ of TBARS values at two days of storage, especially in organic $\mathrm{Cr}$ at level of $1500 \mu \mathrm{g} \mathrm{kg}^{-1}$. The data showed that, although the effects of $\mathrm{Cr}$ source and supplementation level on TBARS on the 6th days of storage, were not significant $(p>0.05)$, there was a trend for decreasing in lipid oxidation in thigh and breast meat.

Moisture, lipid and protein: Moisture and lipid of thigh and breast meat were not affected by $\mathrm{Cr}$ supplementation (Table 2). These results were similar to observation of Mooney and Cromwell ${ }^{[22]}$ when pigs were fed by $\mathrm{Cr}$ picolinate or $\mathrm{Cr}$ chloride, tissue fat and moisture were not affected. However, Kim et al. ${ }^{[23]}$ reported in broiler chicks, supplementing the $\mathrm{Cr}$ picolinate in the diets decreased fat content of the carcass. The $\mathrm{Cr}$ has been found to exert inhibitory effects on in vitro lipogenic activity in chick and pig adipose tissue ${ }^{[23,24]}$. However Lambert and Jacqumin ${ }^{[25]}$ reported insulin inhibits gluconeogenesis and depresses adipocyte lipolysis by reducing the activities of adenylate cyclase and hormone-sensitive lipase.

In the present study Supplemental $\mathrm{Cr}$ increased muscle protein (Table 2). Amayta et al. ${ }^{[12]}$ observed an increase of the protein level in muscles of broilers fed a diet supplemented with $\mathrm{Cr}$ in the form of $\mathrm{Cr}$ chloride or $\mathrm{Cr}$ yeast. Samanta et al. ${ }^{[13]}$ reported meat protein accretion improved in broiler fed organic $\mathrm{Cr}$ under heat stress condition. Also increasing in protein levels in the carcass and liver of broilers given $\mathrm{Cr}$ picolinate were observed $^{[14,23]}$. Cr has been shown to potentiate insulin action by enhancing its binding to the target cell receptors and also by improving its post receptor signaling. Insulin is known as primary hormone regulating glucose cellular absorption and utilisation. In 
chickens, insulin is also known to increase the protein synthesis, efficiency of amino acid transport and diminished protein degradation rate ${ }^{[26,27]}$. The mechanism of insulin action on protein metabolism is not clarified yet, but it was shown by Bigot et al. ${ }^{[28]}$ that S6K1 in chickens, known as potent regulator of protein synthesis in mammals, is activated by insulin. The present investigation revealed that the effects of organic $\mathrm{Cr}$ is more than inorganic on meat quality. It has been reported in swine that supplementation of organic $\mathrm{Cr}$ utilized more efficiently than inorganic $\mathrm{Cr}$ sources ${ }^{[22,29]}$.

pH value: The muscle $\mathrm{pH}$ tended to increase in $\mathrm{Cr}$ supplemented groups (Table 2). In agreement with our results, increasing in muscle $\mathrm{pH}$ was reported in broilers $^{[12]}$ and pigs $^{[30]}$ fed Cr. However, Matthews et al.$^{[31]}$ observed the $\mathrm{pH}$ of loin muscle $24 \mathrm{~h}$ after slaughter was not affected by $\mathrm{Cr}$ in pig. Stress before slaughter can lead to increased muscle glycogen breakdown and glycolysis after slaughter and then the increased muscle lactic acid lowers the $\mathrm{pH}$ of meat. The mechanism of dietary $\mathrm{Cr}$ to influence $\mathrm{pH}$ of the muscle after slaughter could be explained by the roles of $\mathrm{Cr}$ to reduction the stress-induced catecholamine secretion ${ }^{[13,16]}$ and then inhibited glycogen breakdown and glycolysis.

Lipid oxidation: Oxidation of lipids is a major cause of deterioration in the quality of meat and can directly affect many meat characteristics such as flavor, color, texture, nutritive value and safety of the meat ${ }^{[32]}$. The balance between antioxidants and prooxidants and the composition of skeletal muscle influences the susceptibility of muscle lipids to oxidation ${ }^{[33]}$.

According to Table 3 the higher extent of lipid oxidation in thigh meat than breast meat was due to the variation on the heme pigment of the two meats. According to Jones ${ }^{[34]}$, the concentration of heme pigments in breast and thigh meat of broilers is 0.5 and $1.7 \mathrm{mg} \mathrm{g}^{-1}$, respectively. The oxidation of the pigment may have catalyzed the lipid oxidation, as reported by Monahan et al. ${ }^{[35]}$. In the present study, lipid oxidation was affected by supplemental $\mathrm{Cr}$ (Table 3). It is well known that $\mathrm{Cr}$ plays an important role as integral component of the Glucose Tolerance Factor (GTF), which potentiate the action of insulin and regulate fat metabolism ${ }^{[36]}$. It has been well recognized that insulin metabolism influences lipid peroxidation ${ }^{[37]} . \mathrm{Cr}$ is insulin cofactor, therefore postulated to function as an antioxidant ${ }^{[38]}$. According to antioxidant theory ${ }^{[39]}$, when the concentrations of antioxidant vitamins (vitamin $\mathrm{C}$ and $\mathrm{E}$ ) decrease, lipid peroxidation increases in the plasma and tissues, leading to damage of cell membranes. Sahin et al. ${ }^{[40]}$ reported supplemental $\mathrm{Cr}$ resulted in an increase in serum concentrations of vitamin $\mathrm{C}$ and $\mathrm{E}$ and decrease in malonaldehyde concentration in serum of heat-stressed broiler chicks. Preuss et al. ${ }^{[38]}$ reported decreased hepatic TBARS formation upon supplementation of $\mathrm{Cr}$ picolinate and nicotinate in rats. Similarly Anderson et al.$^{[41]}$ also reported the potential beneficial antioxidant effects of the individual and combined supplementation of $\mathrm{Cr}$ and $\mathrm{Zn}$ in Tunisian adult subjects with type 2 diabetes mellitus for 6 months. It seems, studies on $\mathrm{Cr}$ and its effect on meat oxidative are scarce. However, Sahin et al. ${ }^{[42]}$ reported, when Japanes quails were fed by $\mathrm{Cr}$ picolinate, malondialdehyde (MDA) concentration in serum decreased.

\section{CONCLUSION}

It was concluded from the present study that, supplementing the $\mathrm{Cr}$ in the broiler diets, especially organic $\mathrm{Cr}$ at level of $1500 \mu \mathrm{g} \mathrm{kg}^{-1}$ may influence the meat quality in terms of protein content and oxidative stability in broiler chicks reared under heat stress condition.

\section{REFERENCES}

1. Smith, M.O. and G. Teeter, 1987. Influence of feed intake and ambient temperature stress on the relative yield of broiler parts. Nutr. Rep. Int., 35: 299-306.

2. Howlinder, M.A.R. and S.P. Rose, 1989. Rearing temperature and the meat yield of broilers. Br. Poult. Sci., 30: 61-67. DOI: 10.1080/00071668908417125

3. Aksit, M., S. Yalcin, S. Ozkan, K. Metin and D. Ozdemir, 2006. Effects of temperature during rearing and crating on stress parameters and meat quality of broilers. Poult. Sci., 85: 1867-1874. http://ps.fass.org/cgi/content/full//85/11/1867

4. Yalcin, S., A. Onenc, S. Ozkan, H.C. Guler and P.B. Siegel, 2005. Meat quality of heat stressed broilers: Effects of thermal conditioning at preand-postnatal stages. In: Proceeding of the 17th European Symposium on Quality of Poultry Meat, 23-26 May 2005, Doorwerth, The Netherlands, Dutch Branch of the World's Poultry Science Association, pp: 265.

5. Yunis, R. and A. Cahaner, 1999.The effects of naked neck $(\mathrm{Na})$ and frizzle $(\mathrm{F})$ genes on growth and meat yields of broilers and their interactions with ambient temperatures and potential growth rate. Poult. Sci., 78: 1347-1352. http://ps.fass.org/cgi/reprint/78/10/1347 
6. National Research Council, 1997. The Role of Chromium in Animal Nutrition. National Academy Press, Washington, DC.

7. Anderson, R.A. and A.S. Kozlovsky, 1985. Chromium intake, absorption and excretion of subjects consuming self-selected diets. Am. J. Clin. Nutr., 41:

1177. http://www.ajcn.org/cgi/content/abstract/41/6/1177

8. McCarty, M.F., 1993. Homologous physiological effects of phenformin and chromium picolinate. Med. Hypotheses, 41: 316-324. DOI: 10.1016/0306-9877(93)90073-Y

9. Ohba, H., Y. Suzuki and H. Ohba, 1986. Enhancement of ribonucleic acid synthesis by chromium (III)-bound chromatin. J. Inorg. Biochem., 27: 179-188. DOI: 10.1016/01620134(86)80059-9

10. Borel, J.S., T.C. Majerus, M.M. Polansky, P.B. Mozer and R.A. Anderson, 1984. Chromium intake and urinary $\mathrm{Cr}$ excretion of trauma patients. Biol. Trace Element Res., 6: 317-326. http://www.springerlink.com/content/120549

11. Anderson, R.A., N.A. Bryden, M.M. Polansky and P.A. Deuster, 1988. Exercise effects on chromium excretion of trained and untrained men consuming a constant diet. J. Appl. Physiol., 64: 249-252. http://jap.physiology.org/cgi/reprint/64/1/249

12. Amatya, J.L., S. Haldar and K. Ghosh, 2004. Effect of chromium supplementation from inorganic and organic sources on nutrient utilization, mineral metabolism and meat quality in broiler chicks exposed to natural heat stress. Anim. Sci., 97: 241-253. DOI: 1357-7298/04/36050241

13. Samanta, S., S. Haldar, V. Bahadur and T.K. Ghosh, 2008. Chromium picolinate can ameliorate the negative effects of heat stress and enhance performance, carcass and meat traits in broiler chickens by reducing the circulatory cortisol level. J. Sci. Food Agric., 88:787-796. DOI: $10.1002 /$ jsfa.3146

14. Ward, T.L., L.L. Southern and S.L. Boleman, 1993. Effect of dietary chromium picolinate on growth, nitrogen balance and body composition of growing broiler chicks. Poult. Sci., 72: 37(Abstr.). http://www.poultryscience.org/pab93toc.htm

15. Debski, B., W. Zalewski, M.A. Gralak and T. Kosla, 2004. Chromium yeast supplementation of broilers in an industrial farming system. J. Trace Element Med. Biol., 18: 47-51. DOI:10.1016/j.jtemb.2004.02.003
16. Sahin, K., N. Sahin, M. Onderci, F. Gursu and G. Cikim, 2002. Optimal dietary concentration of chromium for alleviating the effect of heat stress on growth, carcass qualities and some serum metabolites of broiler chickens. Biol. Trace Element Res., 89: 53-64. DOI: 01634984/02/8901-0053

17. National Research Council, 1994. Nutrient Requirements of Poultry. $9^{\text {th }}$ Rev. Edn. National Academy Press, Washington, DC.

18. AOAC, 1990. Official Methods of Analysis. 15th Edn. Association of Official Analytical Chemists, Arlington, VA.

19. Korkeala, H., O. Maki-Petais, T. Alanko and O. Sorvettula, 1986. Determination of $\mathrm{pH}$ in meat. Meat Sci., 18: 21-125. DOI: 10.1016/03091740(86)90088-4

20. Strange, E.D., R.C. Benedict, J.L. Smith and C.E. Swift, 1977. Evaluation of rapid tests for monitoring alterations in meat quality during storage. I. Intact meat. J. Food Protec., 40: 843-847. http://www.foodprotection.org

21. SAS User`s Guide: Statistics, Version 6.06, 1997. SAS Institute, Inc., Cary, NC.

22. Mooney, K.W. and G.L. Cromwel, 1997. Efficacy of chromium picolinate and chromium chloride as potential carcass modifiers in swine. J. Anim. Sci., 75:2661-2671. http://jas.fass.org/cgi/reprint/75/10/2661

23. Kim, Y.H., I.K. Han, Y.J. Choi, I.S. Shin, B.J. Chae and T.H. Kang, 1996. Effects of dietary levels of chromium picolinate on growth performance car cass quality and serum traits in broiler chicks. Asian-Aust J. Anim. Sci., 9: 341-347. http://www.ajas.info/

24. Min, J.K., W.Y. Kim, B.J. Chae, I.B. Chung, I.S. Shin, Y.J. Choi and K. Han, 1997. Effect of chromium picolinate on growth performance, carcass characteristics and serum traits in growingfinishing pigs. Asian-Aust J. Anim. Sci. 10: 8-14. http://www.ajas.info/

25. Lambert, B. and C. Jacquemin, 1979. Inhibition of epinephrine induced lipolysis in isolated white adipocytes of aging rabbits by increased alphaadrenergic responsiveness. J. Lipid Res.,20:208-216. http://www.jlr.org/cgi/reprint/20/2/208

26. Sakhari, M., M.K. Jeacock and D.A. Shepherd, 1992. Regulation of intracellular protein degradation in the isolated perfused liver of the chicken (Gallus domesticus). Comp. Biochem. Physiol. 101: 17-21. DOI:10.1016/03050491(92)90152-H 
27. Duclos, M.J., B. Chevalier, C. Goddard and J. Simon, 1993. Regulation of amino acid transport and protein metabolism in myotubes derived from chicken muscle satellite cells by insulin-like growth factor-I. J. Cell Physiol., 157: 650-657. DOI: $10.1002 /$ jcp. 1041570327

28. Bigot, K., M. Taouis and S. Tesseraund, 2003. Refeeding and insulin regulate S6K1 activity in chicken skeletal muscles. J. Nutr., 133: 369-373. http://jn.nutrition.org/cgi/content/full/133/2/369

29. Page, T.G., L.L. Southern, T.L. Ward and D.L. Thompson, 1993. Effect of chromium picolinate on growth and serum and carcass traits of growing-finishing pigs. J. Anim. Sci., 71: 656. http://jas.fass.org/cgi/reprint/71/3/656

30. Matthews, J.O., A.C. Guzik, F.M. Le Mieux, L.L. Southern and T.D. Bidner, 2005. Effects of chromium propionate on growth, carcass traits and pork quality of growing-finishing pigs. J. Anim. Sci., 83:858-862. http://jas.fass.org/cgi/content/full/83/4/858

31. Matthews, J.O., A.D. Higbie, L.L. Southern, D.F. Coombs, T.D. Bidner and R.L. Odgaard, 2003. Effect of chromium propionate and metabolizable energy on growth, carcass traits and pork quality of growing-finishing pigs. J. Anim. Sci., 81: 191-196. http://jas.fass.org/cgi/content/full/81/1/191

32. Buckley, D.J., P.A. Morrissey and J.I. Gray, 1995. Influence of dietary vitamin $\mathrm{E}$ on the oxidative stability and quality of pig meat. J. Anim. Sci., 73:

3122-3130.

http://jas.fass.org/cgi/reprint/73/10/3122

33. Lauridsen, C., D.J. Buckley and P.A. Morrissey, 1997. Influence of dietary fat and vitamin E supplementation on a-tocopherol levels and fatty acid profiles in chicken muscle membranal fractions and on susceptibility to lipid peroxidation. Meat Sci., 46: 9-22. DOI:10.1016/S03091740(97)00010-7

34. Jones, J.M., 1992. Factors Influencing Poultry Meat Quality. In: The Chemistry of Muscle-Based Foods, Johnston, D.E., M.K. Knight and D.A. Ledward (Eds). Society of Chemistry, Cambridge, pp: 27-39.
35. Monahan, F.J., D.J. Buckley, P.A. Morrissey, P.B. Lynch and J.I. Gray, 1992. Influence of dietary fat and alpha-tocopherol supplementation on lipid oxidation in pork. Meat Sci., 31: 229-241. DOI:10.1016/0309-1740(92)90042-3

36. Mertz, W., 1993. Chromium in human nutrition: A review. J. Nutr., 123: 626-633. http://jn.nutrition.org/cgi/content/abstract/123/4/62 6

37. Gallaher, D.D., A.S. Csallany, D.W. Shoeman and J.M. Olson, 1993. Diabetes increases excretion of urinary malondehyde conjugates in rats. Lipids, 28: 663-666. DOI: 10.1007/BF02536063

38. Preuss, H.G., P.L. Grojec, S. Lieberman and R.A. Anderson, 1997. Effects of different chromium compounds on blood pressure and lipid peroxidation in spontaneously hypertensive rats. Clin. Nephrol., 47: 325-330. http://www.dustri.de/nc/journals-in-english/mag/ clinical-nephrology.html

39. Klasing, K.C., 1993. Comparative Avian Nutrition. University Press, Cambridge, pp. 277-299.

40. Sahin, K., N. Sahin and O. Kucuka, 2003. Effects of chromium and ascorbic acid supplementation on growth, carcass traits, serum metabolites and antioxidant status of broiler chickens reared at a high ambient temperature. Nutr. Res., 23: 225-238. DOI:10.1016/S0271-5317(02)00513-4

41. Anderson, R.A., A.M. Roussel, N. Zouari, S. Majhoub, J.M. Matheau and A. Kerkeni, 2001. Potential antioxidant effects of zinc and chromium supplementation in people with type 2 diabetes mellitus. J. Am. College Nutr., 20: 212-218. http://www.jacn.org/cgi/content/full/20/3/212

42. Sahin, N., K. Sahin, M. Onderci, M. Ozcelik and M.O. Smith, 2003. In vivo antioxidant properties of vitamin $\mathrm{E}$ and chromium in cold-stress Japanese quails. Arch. Anim. Nutr., 57: 207-215. DOI: 10.1080/0003942031000136639 